Proc. Estonian Acad. Sci. Geol., 1999, 48, 4, 228-250

\title{
HOLOCENE AND CURRENT CHANGES IN FOREST STAGNIC LUVISOL
}

\author{
Loit REINTAM
}

Institute of Soil Science and Agrochemistry, Estonian Agricultural University, Viljandi mnt., Eerika, 51014 Tartu, Estonia

\section{Received 12 February 1999}

\begin{abstract}
Chromi-Stagnic Luvisol sections both on the drumlin summit and slope were studied in 1969-72 and 1994 in two International Biological Programme areas at the Vooremaa Forest Ecology Station. The studies were aimed to determine changes in the composition and properties of these soils during the entire Holocene as well as some recent decades.

The trisequal profile of Chromi-Stagnic Luvisol (A-Baf-ELg-Bt-C) developed on reddishbrown calcareous till during the Holocene as a result of the weathering of sand particles and accumulation of silt, clay, and most chemical constituents. Current changes in soil characteristics have been due to changes in the fluxes of organic matter and in the perched water regime induced by clear-cutting and/or selection felling. Besides mineralization of falling litter, partial mineralization of humus has taken place, while losses have been more significant on the drumlin summit. Simultaneously with a decrease in the percentage of organic carbon, its pool has lowered to a lesser extent; the solubility and fulvicity have increased, and the degree of humification and perfection (according to the $\mathrm{C}: \mathrm{N}$ ratio) of humus has decreased. Changes in the composition of decalcinate (extraction of $0.05 \mathrm{M}$ sulphuric acid) demonstrate the increased role of $\mathrm{Fe}, \mathrm{Ca}$, and $\mathrm{Mg}$, and the decreased role of $\mathrm{Al}$ in complexiation of humus. Mobilization of exchangeable $\mathrm{Al}^{3+}$ in the epipedon and in the uppermost part of the Baf-horizon has taken place. This has resulted in an increase in actual acidity and, by layers, also in cation exchange capacity and base saturation. Extrinsic acidification has been somewhat greater than intrinsic acidification. Against the background of the decrease in the content of nonsiliceous iron, the accumulation of amorphous iron, increase in iron activity as well as the formation of secondary Fe-silicates were established. Amorphous aluminium and silica have been stable; reciprocal changes in the percentages of aluminium and alkaline earths seem to outline potential changes in the structure of clay minerals against the background of increased acidity. Weathering of sandy fractions has been accompanied by the significant formation and accumulation of silty and clayey particles. On the drumlin summit this phenomenon may also be due to the territorial heterogeneity of till mantle.
\end{abstract}

Key words: Holocene pedogenesis, current pedogenesis, changes in soils, Stagnic Luvisol.

\section{INTRODUCTION}

Temporal and spatial changes in soil characteristics reflect best the kinetics and statics as well as the dynamics and stability of the development of soil 
processes (Zonn, 1986, 1994). During pedogenesis, part of changes will be permanently deposited in the memory of soil, while another part can reflect only the status of the moment (Sokolov \& Targulian, 1976). That is why soil genesis belongs to natural fundamentals which are always topical and cannot be conclusively solved for any instant (Buol et al., 1989). Only a few long-term experiments have been performed for the observation of pedogenetic phenomena and for their quantitative evaluation (Wang \& Arnold, 1973) and modelling (Bryant \& Arnold, 1994). By using special experimental models it has been established that changes in the fluxes and dynamics of organic agents and in textural and chemical soil constituents have occurred already during some 20 or 30 years (Graham et al., 1995; Reintam, 1995, 1997b). Of course, these changes developed against the background of pedogenesis during the entire Holocene, and the climatic and biocoenotic fluctuations of that period must have been expressed in the cyclicity of pedogenesis too. Unfortunately, certain analytical data for times millennia ago are lacking, and any calculation of the rate and character of Holocene pedogenesis would yield information about processes that have occurred only during some millennia (Creemens, 1995) or during the whole long period of organic-mineral interactions (Targulian et al., 1974; Reintam, 1985). Therefore genetic memory is fairly well fixed in any individual soil section and can be opened with the help of analytical interpretation of the obtained data. Pedogenetic phenomena of any past moment have become lost in time and/or, as a result of stabilization processes, have accumulated in soil's memory. Only special studies of active soil processes would allow characterization of their status during some last dozens of years.

To obtain coherent pedogenetic information on the basis of organic-mineral interactions occurring during the entire Holocene and at present, this paper focuses on changes in reddish-brown calcareous till in which soil formation was initiated after the retreat of the Fennoscandian ice-shield some 12000 BP (Huckriede et al., 1996), as well as on modern changes in a Chromi-Stagnic Luvisol that have taken place under natural processes and human activity during the last quarter of the 20th century. As local ice lakes could occur in the interdrumlin hollows (Raukas et al., 1995), possible pedogenesis within the Bölling Stage earlier than 12000 BP was excluded.

\section{MATERIAL AND METHODS}

\section{Layout, area, and sampling}

Investigations were carried out in two International Biological Programme (IBP) areas at the Vooremaa Forest Ecology Station, Jõgeva County, Estonia $\left(58^{\circ} 42^{\prime}-58^{\circ} 43^{\prime} \mathrm{N}, 26^{\circ} 41^{\prime}-26^{\circ} 44^{\prime} \mathrm{E}\right)$, both on the summit and northeastern slope of Kallivere drumlin (Photo 1) covered with nemoral spruce forest (Frey, 1977). The first studies of Chromi-Stagnic Luvisol (brown pseudopodzolic soil - a typological unit used in Estonia; Glossaquic Eutroboralf - USDA Soil Taxonomy) 


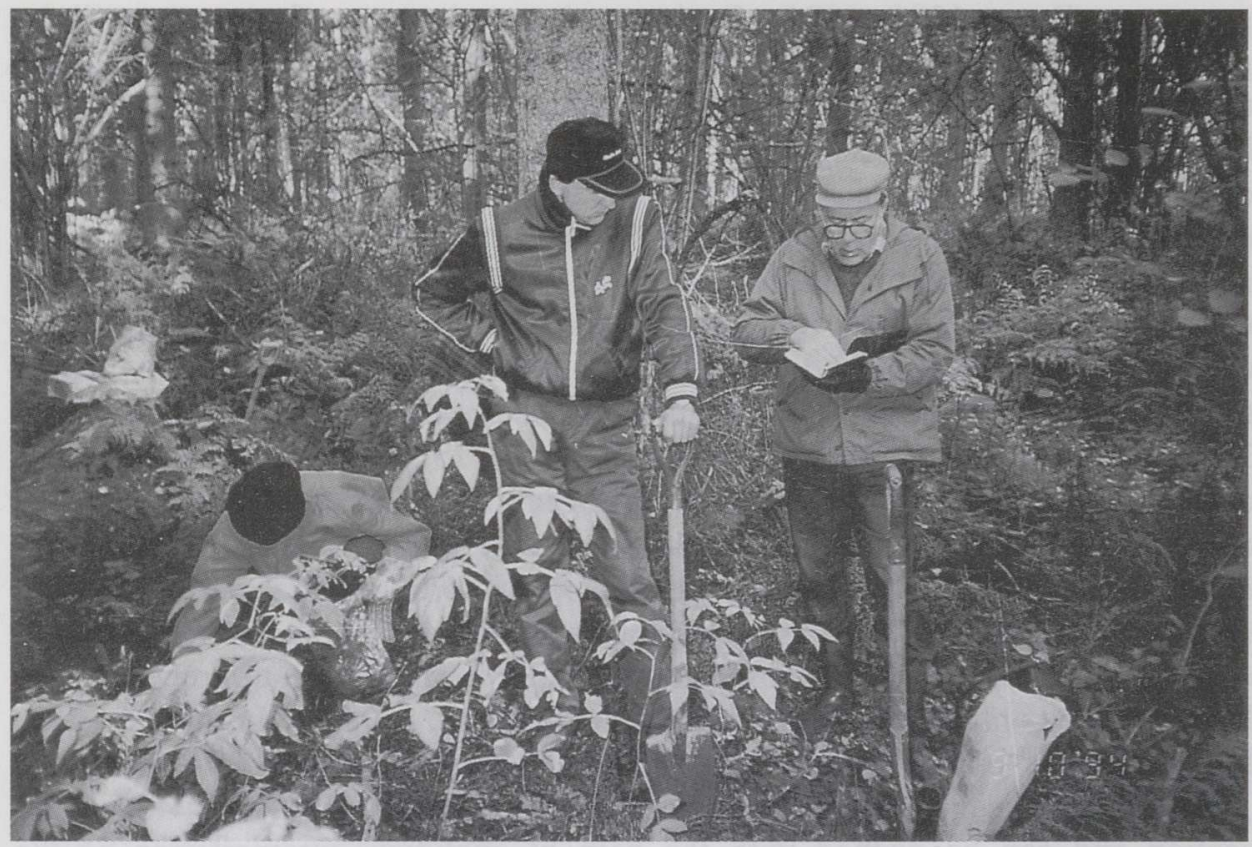

Photo 1. Field studies in 1994 in the forest where selection felling had been carried out. Photo by Toomas Frey.

were made on 18 Sept. 1969 (summit) and on 4 Oct. 1972 (slope). The obtained results were published in the series Estonian Contributions to the IBP (Reintam et al., 1977; Reintam \& Kaasik, 1977) and in the Year-Book of the Estonian Naturalists' Society (Reintam \& Oja, 1978). These publications also contained a discussion on the genetic uniformity of reddish-brown till on the studied drumlin. According to the suggestions of Wang \& Arnold (1973), textural, mineralogical, and chemical differentiation, morphological phenomena as well as respective relationships demonstrated the lack of lithological discontinuity, but pedogeneticgeological transformation of the uppermost part of till was plausible in the periglacial zone during the Early Holocene (Reintam et al., 1977). Recurrent investigations were performed on 19 Oct. 1994, some years after clear-cutting and/or selection felling activities. No principal changes in soil morphology and profile structure were established.

In all cases soils were described and sampled by their genetic horizons (at first to a depth of $200 \mathrm{~cm}$ ), separately for the determination of bulk density (in four replications using a barrel of $50 \mathrm{~cm}^{3}$ ) and for laboratory analysis. The bulk densities of 1.70 and $1.66 \mathrm{Mg} \mathrm{m}^{-3}$, determined at a depth of $180-200 \mathrm{~cm}$, were used in the characterization of initial till on the drumlin summit and slope, respectively. Sampling of soils to determine changes in their composition and properties was performed on 19 Oct. 1994 (Photo 2) either from two former pits 


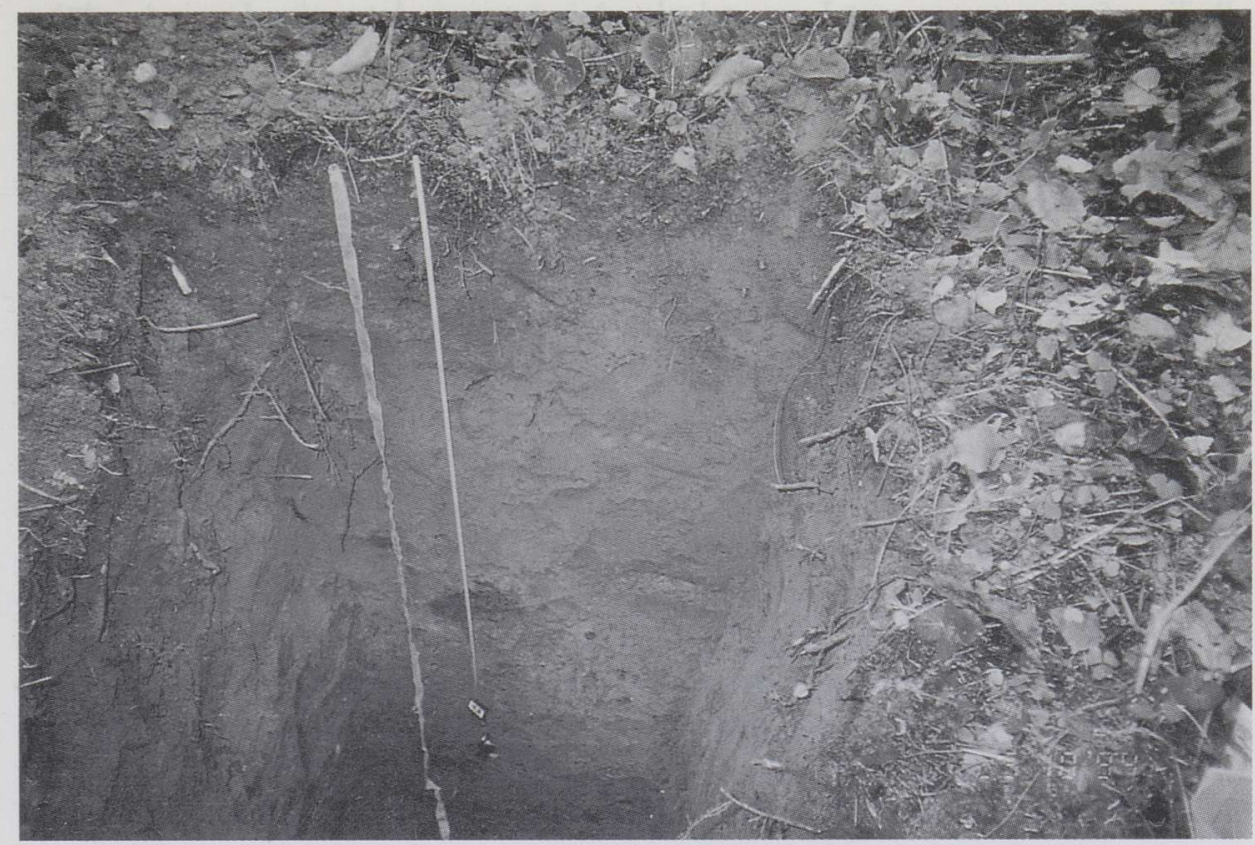

Photo 2. Profile No. 4 of Chromi-Stagnic Luvisol (A-Baf-ELg-Bt) on the drumlin slope in 1994. Photo by Toomas Frey.

(drumlin slope) or from a place very near (within some metres) to it (drumlin summit). The use of the former pit was impossible on the drumlin summit, because after the first sampling in 1969 this trench was exploited for setting lysimetric vessels and chromatographic columns and was damaged after their removal. The bulk density of unchanged till was the same, but soil horizons on the drumlin summit were more compact and seemed to be enriched with silt and clay (see discussion) in 1994. Some vertical discontinuity and morphological heterogeneity was detected in the process of sampling.

\section{Analyses}

Analyses were carried out at the laboratories of the Institute (Department) of Soil Science \& Agrochemistry, Estonian Agricultural University: in 1969-72 by a team of coworkers listed in the title of the IBP publication (Reintam et al., 1977) and from 1994 onward by Raja Kährik, who participated in the former team too. To obtain comparable results in both cases, the same methods were applied in analytical techniques. Fine earth less than $1 \mathrm{~mm}$ was used. Samples for the determination of particle size were treated with sodium pyrophosphate to break up aggregates. Sands were sieved and fractions finer than $0.05 \mathrm{~mm}$ were determined by pipette analysis. Total chemical analysis was carried out after 
alkaline fusion treatment. Iron and aluminium were determined using sulphosalicylic acid and aluminone, respectively; alkaline earths, by complexometric method with the use of trilon B; potassium and sodium, by the method of flame photometry (Arinushkina, 1970). The authenticity of these techniques was in 1994 verified by the method of atomic absorption spectrometry. Results of particle size and chemical analyses were expressed per ignited noncalcareous material.

The group and fractional composition of humus was determined by alternate acid-alkaline treatment after the Tyurin-Ponomareva volumetric method (Ponomareva, 1957). The results obtained were expressed in percentages of organic carbon. The total percentages of organic carbon and nitrogen were established by the Tyurin and Kjeldahl methods, respectively. Nonsiliceous iron was determined after Coffin, amorphous sesquioxides and silica, after Tamm, and iron activity, after Schwertmann (Zonn, 1982). $\mathrm{pH}$ of water and $1 \mathrm{M} \mathrm{KCl}$ suspension was measured with the help of a glass electrode; exchange acidity and exchangeable $\mathrm{Al}^{3+}$ were determined after Daikuhara-Sokolov, base exchange capacity $(B E C=T)$ and base saturation $(B S=V)$ after Kappen (Arinushkina, 1970). Average values of analytical data were used for the drumlin slope where 10 and 2 soil pits were sampled in 1972 and 1994, respectively. Supplies of granulometric fractions and chemical elements were calculated on the basis of particular thickness of the described layers (horizons) and determined bulk density. Changes in soil constituents and properties were expressed as deviations ( \pm of the unit used) from initial quantity values published in Estonian Contributions to the IBP (Reintam et al., 1977). Part of these changes were discussed at the 7th Estonian Conference on Ecology (Reintam, 1997a).

\section{Calculation of changes in till and soil constituents}

To establish the quantitative origin of profile differentiation within both Holocene and contemporary pedogenesis, the material balance method was used (Targulian et al., 1974; Reintam, 1985, 1990). Differences in the weight of formed soil horizons as well as their textural and chemical constituents were compared with those occurring in initial reddish-brown till prior to pedogenetic interactions as follows:

$$
y=M\left(B D_{1} \cdot x_{1}-B D_{0} \cdot x_{0}\right),
$$

where $y$ is the difference in the weight of the investigated fractions (elements) compared to the initial, $\pm \mathrm{kg} \mathrm{m}^{-2} ; M$ is the thickness of the formed soil horizon and the corresponding initial till, dm; $B D_{1}$ is the bulk density of soil; $B D_{0}$ is the bulk density of initial material $\left(1.70\right.$ and $1.66 \mathrm{Mg} \mathrm{m}^{-3}$ on the drumlin summit and slope, respectively); $x_{1}$ is the percentage of the fraction (chemical) examined in soil; $x_{0}$ is the percentage of the fraction (chemical) examined in initial till. 
The same equation was used for the calculation of quantitative changes that have taken place in soil constituents during contemporary interactions; the measured data of 1969-72 were taken as initial values $\left(B D_{0}, x_{0}\right)$ and those of 1994 , as the outcome of changes $\left(B D_{1}, x_{1}\right)$.

Since any change in initial bulk density in the course of pedogenesis brings about a change in the total weight of the respective horizon, the thickness of the horizon and the amount of all constituents therein, the trends and character of transformations were explained with the help of mineral indicators (Rozanov, 1975). The fractions of sand and coarse silt $(>0.01 \mathrm{~mm})$, resistant to biological weathering and pedogenesis, were regarded as an indicator of the initial status of the parent till. Formation of both humus and organomineral complexes and structural aggregates, characteristic of pedogenesis, is always connected with the loosening of soil and the upward growth of the profile formed. Vice versa, compacting of the formed solum results in the subsidence of the soil section with a simultaneous relative accumulation of resistant indicators (Targulian et al., 1974; Rozanov, 1975; Reintam, 1985, 1990). Changes in the thickness of the initial till prism which represents a column of layers and/or horizons with the area of one square metre (CTITP $\pm \mathrm{cm})$ were calculated as follows:

$$
C T I T P=\frac{T S \cdot C W I}{W I T}
$$

where TS is the thickness of the studied solum (180 and $120 \mathrm{~cm}$ on the drumlin summit and slope, respectively); WIT is the weight of indicators (particles $>0.01 \mathrm{~mm})$ in till $\left(\mathrm{kg} \mathrm{m}^{-2}\right)$; CWI denotes changes in the weight of indicators during pedogenesis $\left( \pm \mathrm{kg} \mathrm{m}^{-2}\right)$.

The same equation was used again for recalculation of the thickness of soil prism as changing from 1969-72 to 1994, while the former status was analogized to till thickness and the latter (1994), to soil thickness in Eq. (2).

Carbonates in sand and coarse silt fractions cannot be used as indicators. Their pedogenetic breakdown leads to a decrease in the weight of the solum, whereas residual crystalline indicators (quartz, unchanged feldspars, etc.) are available to reveal the character of transformation processes. Such recalculation of the thickness of the initial till and/or soil (1969-72) prism allowed us to take into consideration the upward growth and/or downward subsidence of the stratum during Holocene and/or contemporary pedogenesis, as well as to find out real changes in textural and chemical constituents:

$$
S W T=\frac{W C T \cdot S T}{T S}
$$

where $S W T$ is smoothed (corrected) weight of a constituent in till (soil) with smoothed (corrected) thickness; WCT is the weight of a constituent in till and/or soil in 1969-72 $\left(\mathrm{kg} \mathrm{m}^{-2}\right) ; T S$ is the thickness of a horizon (solum); $S T$ is 
smoothed (corrected) thickness of the corresponding prism of initial till (soil in 1969-72).

Smoothed (corrected) thickness, calculated on the basis of sand and silt indicators, was also used in recalculation of changes in chemical constituents. This method has been applied successfully not only by Targulian et al. (1974) and by the author of this paper (Reintam, 1985, 1997b), but also by numerous other researchers cited in the above publications.

\section{RESULTS AND DISCUSSION}

\section{Changes in reddish-brown till during the Holocene}

The depth of the solum that formed on reddish-brown till during the Holocene was 180 and $120 \mathrm{~cm}$ on the drumlin summit and slope, respectively (Reintam et al., 1977). Total accumulated organic carbon and nitrogen amounted to 8.35 and $0.65 \mathrm{~kg} \mathrm{~m}^{-2}$ on the drumlin summit and to 7.85 and $0.74 \mathrm{~kg} \mathrm{~m}^{-2}$ on the slope. The rate of mean annual increment was $654-696 \mathrm{mg} \mathrm{m}^{-2}$ for carbon and 54-62 mg m $\mathrm{mg}^{-2}$ for nitrogen there, while the process was probably characterized by temporal and spatial cyclings. On the basis of a large selection, an accumulation of nearly the same order was found in Boralfs in the Contiguous United States (Kern, 1994). According to Knoepp \& Swank (1997), even harvest treatments have an impact on soil carbon and nitrogen status, not to mention changes in the climatic and biocoenotical situation during the stages of the Holocene.

Of organic carbon $48-49 \%$ and of nitrogen $42-43 \%$ are concentrated in the uppermost $20 \mathrm{~cm}$ (10YR3/3 moist and 10YR5/3 dry), whereas only $19-28 \%$ and $30-32 \%$, respectively, are distributed deeper than $50 \mathrm{~cm}$. The presence of organic agents whose average amount is $540-570 \mathrm{mg} \mathrm{m}^{-2} \mathrm{yr}^{-1}$ of carbon and nitrogen in the upper half-metre has ensured the progress of chromic properties of Luvisol. The yellowish-brown cambic Baf-horizon (7.5YR4/6 moist and 7.5YR6/6 dry) below the epipedon is enriched with amorphous sesquioxides, is finely rooted, crumbly aggregated, and rich in worm casts. The remaining portion of carbon and nitrogen (140-210 $\mathrm{mg} \mathrm{m}^{-2} \mathrm{yr}^{-1}$ ) that has accumulated within and below the belt of seasonal perched water seems to have affected the development of stagnic properties and a whitish ELg-horizon (7.5YR7/3 moist and 7.5YR8/2 dry), argillization of till constituents in situ, and argilluviation within the entire solum signed as Bt (5YR4/4 moist and 7.5YR5/4 dry). Since the amounts of organic agents are greater on the drumlin summit, the progress of pedogenesis appears to be favoured there.

Weathering of sand fractions and translocation of fine-dispersed particles were characteristic of Holocene pedogenesis in the drumlin landscape (Table 1). In spite of slight accumulation of coarse silt, total decrease in the weight of fine earth, making up 9-13\% of the initial weight of till prisms, seems to be related mainly to the breakdown and leaching of carbonates whose content in sand and 
silt of till was $8.0 \%$ and $10.3 \%$, respectively (Reintam et al., 1977). The impact of surface gleyization on the transformation of alumosilicates during the PreBoreal and lateral migration of mobilized products cannot be excluded there either. This caused the annual decrease in initial till mass of $22-23 \mathrm{~g} \mathrm{~m}^{-2} \mathrm{yr}^{-1}$ of fine earth without any remnant accumulation of mineral indicators $>0.01 \mathrm{~mm}$ during the entire Holocene. Except in the eluvial stagnic horizon, the loosening and upward growth of formed soil sections have taken place. This phenomenon is quite similar to the one described and discussed earlier (Wang \& Arnold, 1973; Rozanov, 1975; Reintam, 1985) as well as to the one established within primary pedogenesis on reddish-brown calcareous till (Reintam, 1997b).

Considering the layeral status of mineral indicators, soil sections of 120 $180 \mathrm{~cm}$ that developed during the Holocene represent a real outcome of pedogenetic impacts on the initial till stratum which was by $13-18 \mathrm{~cm}$ thinner and $10-11 \%$ lighter (Tables 1 and 2). An average annual upgrowth of 11-15 $\mu \mathrm{m}$

Table 1. Changes in the weight of granulometric fractions of soil compared with initial reddishbrown till during the Holocene $\left( \pm \mathrm{kg} \mathrm{m}^{-2}\right)$

\begin{tabular}{|c|c|c|c|c|c|c|c|}
\hline \multirow{2}{*}{$\begin{array}{l}\text { Horizon } \\
\text { and depth, } \\
\mathrm{cm}\end{array}$} & \multicolumn{2}{|c|}{ Weight of prisms } & \multicolumn{4}{|c|}{ Fractions } & \multirow{2}{*}{$\begin{array}{c}\text { Corrected } \\
\text { depth of till } \\
\mathrm{cm}\end{array}$} \\
\hline & Initial till & Soil & Sand & Coarse silt & $\begin{array}{l}\text { Phys. } \\
\text { clay* }\end{array}$ & $\begin{array}{c}\text { Total fine } \\
\text { earth }\end{array}$ & \\
\hline
\end{tabular}

Summit of the drumlin

$\begin{array}{lrrrrrrr}\text { A 0-10 } & 170.0 & 99.0 & -54.2 & -0.2 & -16.6 & -71.0 & 5.9 \\ \text { A 10-20 } & 170.0 & 117.0 & -45.4 & +5.2 & -12.8 & -53.0 & 7.0 \\ \text { Baf 20-30 } & 170.0 & 137.0 & -29.3 & +9.0 & -12.7 & -33.0 & 8.5 \\ \text { Baf 30-40 } & 170.0 & 147.0 & -23.0 & +10.9 & -10.9 & -23.0 & 9.1 \\ \text { ELg 40-50 } & 170.0 & 157.0 & -5.7 & +8.1 & -15.4 & -13.0 & 10.2 \\ \text { ELg/Bt 50-70 } & 340.0 & 318.0 & -24.5 & +20.1 & -17.6 & -22.0 & 19.6 \\ \text { Bt 70-90 } & 340.0 & 328.0 & -31.2 & +21.8 & -2.6 & -12.0 & 19.3 \\ \text { Bt 90-120 } & 510.0 & 487.0 & -74.1 & +26.9 & +24.2 & -23.0 & 26.4 \\ \text { Bt 120-180 } & 1020.0 & 998.0 & -74.8 & +27.7 & +25.1 & -22.0 & 56.4 \\ \text { Total } & 3060.0 & 2788.0 & -362.2 & +129.5 & -39.3 & -272.0 & 162.4\end{array}$

Slope of the drumlin

$\begin{array}{lrrrrrrr}\text { A 0-10 } & 166.0 & 105.8 & -37.8 & +0.4 & -22.8 & -60.2 & 7.0 \\ \text { A/Baf 10-20 } & 166.0 & 114.3 & -32.1 & +0.1 & -19.7 & -51.7 & 7.4 \\ \text { Baf 20-35 } & 249.0 & 192.5 & -37.2 & +3.3 & -22.6 & -56.5 & 12.3 \\ \text { Baf 35-50 } & 249.0 & 222.9 & -3.0 & -4.3 & -18.8 & -26.1 & 14.4 \\ \text { ELg 50-70 } & 332.0 & 301.1 & +2.2 & -5.9 & -27.2 & -30.9 & 19.8 \\ \text { Bt 70-100 } & 498.0 & 471.2 & -31.1 & +3.6 & +0.7 & -26.8 & 27.7 \\ \text { Bt 100-120 } & 332.0 & 317.3 & -13.1 & -5.3 & +3.7 & -14.7 & 18.6 \\ \text { Total } & 1992.0 & 1725.1 & -152.1 & -8.1 & -106.7 & -266.9 & 107.2\end{array}$

* Physical clay represents fractions $<0.01 \mathrm{~mm}$. 
was recorded. The spatial culmination of lessivage progressed within the belt of stagnant perched water, where during the Pre-Boreal prolonged but later seasonal frost actions had reached. This sequum represents the stagni-gleyic formation of primary Gelic Gleysol that could develop under the permafrost during the Baltic Ice Lake Stage about 12 000-10 400 BP (Reintam, 1997c). According to Mermut \& St. Arnaud (1981), freeze-thaw interactions, affecting fine particles, could have later taken place. During thaw seasons, silty and clayey particles could have existed as fluid suspension, which led to the physical separation of these fractions without development of immediate pedogenetic lessivage. Some cambic properties in deep argillic horizons seem to demonstrate the presence of argillization in situ there, while this process was probably favoured during the Litorina Stage and later (Reintam, 1997c). A tendency towards an increase in the corrected (smoothed) weight of granulometric fractions of soil was established only on the drumlin summit. Owing to denudation within recurrent unafforested stages during the Holocene, a decrease in the initial weight of till (3\%) had still taken place on the slope of the drumlin.

Table 2. Changes in the weight of granulometric fractions of soil compared with the corrected (smoothed) thickness of initial reddish-brown till $\left( \pm \mathrm{kg} \mathrm{m}^{-2}\right)$

\begin{tabular}{c|c|c|c|c|c}
\hline \multirow{2}{*}{$\begin{array}{c}\text { Horizon } \\
\text { and depth, } \\
\mathrm{cm}\end{array}$} & \multicolumn{2}{|c|}{ Weight of prisms } & \multicolumn{3}{c}{ Fractions } \\
\cline { 2 - 6 } & Soil & $\begin{array}{c}\text { Smoothed } \\
\text { till }\end{array}$ & $1-0.01 \mathrm{~mm}$ & $<0.01 \mathrm{~mm}$ & Total fine earth \\
\hline
\end{tabular}

$\begin{array}{lrrrrr}\text { A 0-10 } & 99.0 & 100.3 & 0.0 & -1.3 & -1.3 \\ \text { A 10-20 } & 117.0 & 119.0 & -0.4 & -1.6 & -2.0 \\ \text { Baf 20-30 } & 137.0 & 144.5 & -0.4 & -7.1 & -7.5 \\ \text { Baf 30-40 } & 147.0 & 154.7 & -0.2 & -7.5 & -7.7 \\ \text { ELg 40-50 } & 157.0 & 174.1 & -0.2 & -16.9 & -17.1 \\ \text { ELg/Bt 50-70 } & 318.0 & 333.2 & +0.9 & -16.1 & -15.2 \\ \text { Bt 70-90 } & 328.0 & 328.1 & -0.1 & 0.0 & -0.1 \\ \text { Bt 90-120 } & 487.0 & 448.8 & +0.5 & +37.7 & +38.2 \\ \text { Bt 120-180 } & 998.0 & 958.8 & +0.6 & +38.6 & +39.2 \\ \text { Total } & 2788.0 & 2761.5 & +0.7 & +25.8 & +26.5^{*} \\ & & & & & \\ & & \text { Slope of the drumlin } & & \\ \text { A 0-10 } & 105.8 & 116.2 & +0.2 & -10.6 & -10.4 \\ \text { A/Baf 10-20 } & 114.3 & 122.8 & +0.6 & -9.1 & -8.4 \\ \text { Baf 20-35 } & 192.5 & 204.3 & -0.2 & -11.6 & -11.8 \\ \text { Baf 35-50 } & 222.9 & 239.1 & -7.3 & -8.9 & -16.2 \\ \text { ELg 50-70 } & 301.1 & 328.7 & -1.2 & -26.4 & -27.6 \\ \text { Bt 70-100 } & 471.2 & 460.0 & +1.3 & +9.9 & +11.2 \\ \text { Bt 100-120 } & 317.3 & 308.8 & -0.8 & +9.3 & +8.5 \\ \text { Total } & 1725.1 & 1779.9 & -7.4 & -47.4 & -54.8^{* *}\end{array}$

\footnotetext{
* Increase in the initial weight of till $1.0 \%$.

** Decrease in the initial weight of till $3.1 \%$.
} 
Considering the smoothed thickness of initial till, changes in chemical constituents are quite close to changes in granulometric relationships (Table 3). The $4.4 \%$ increase in their amount on the drumlin summit, compared to the initial value, was revealed against the background of argilluviation, but seems primarily to have been due to more developed argillization in situ within the lowermost solum. A slight impoverishment of the Luvisol section in magnesium and potassium could only have been induced by transformation of silicates and their substitution by sesquioxides in the crystal lattice of accumulated secondary products. According to pedogenetic investigations in Coastal Oregon (LangleyTurnbaugh \& Bockheim, 1997), the abundance and amount of clay together with its constituents had increased with the aging of soil while clay neoformation

Table 3. Changes in the weight of chemical constituents of soil compared with the smoothed thickness of initial reddish-brown till during the Holocene $\left( \pm \mathrm{kg} \mathrm{m}^{-2}\right)^{*}$

\begin{tabular}{c|c|c|c|c|c|c|c|c|c}
\hline $\begin{array}{c}\text { Horizon and } \\
\text { depth, } \mathrm{cm}\end{array}$ & $\mathrm{Si}$ & $\mathrm{Fe}$ & $\mathrm{Al}$ & $\mathrm{Ti}$ & $\mathrm{P}$ & $\mathrm{Ca}$ & $\mathrm{Mg}$ & $\mathrm{K}$ & $\mathrm{Mn}$ \\
\hline
\end{tabular}

$\begin{array}{llllllllll}\text { A 0-10 } & +0.9 & -0.6 & -0.6 & 0.0 & -0.01 & +0.1 & -0.3 & -0.1 & -0.016 \\ \text { A 10-20 } & +0.9 & -0.8 & -0.2 & +0.1 & -0.07 & +0.2 & -0.4 & -0.2 & -0.028 \\ \text { Baf 20-30 } & -1.3 & -1.4 & -0.4 & 0.0 & -0.04 & +0.1 & -0.3 & -0.2 & -0.014 \\ \text { Baf 30-40 } & -1.4 & -0.9 & -0.7 & 0.0 & -0.06 & +0.3 & -0.4 & -0.3 & -0.037 \\ \text { ELg 40-50 } & -5.0 & -1.4 & -1.3 & 0.0 & -0.04 & +0.5 & -0.5 & -0.5 & -0.033 \\ \text { ELg/Bt 50-70 } & -5.7 & -0.5 & +0.1 & 0.0 & -0.03 & +0.9 & -0.6 & -0.6 & -0.008 \\ \text { Bt 70-90 } & -2.9 & +1.7 & +2.6 & 0.0 & +0.01 & +0.7 & 0.0 & -0.2 & +0.001 \\ \text { Bt 90-120 } & +7.9 & +4.2 & +6.0 & +0.2 & +0.05 & +1.0 & +0.4 & +0.7 & -0.017 \\ \text { Bt 120-180 } & +8.3 & +4.3 & +6.4 & +0.1 & +0.04 & +0.9 & +0.5 & +1.0 & +0.023 \\ \text { Total } & +1.7 & +4.6 & +11.9 & +0.4 & -0.15 & +4.7 & -1.6 & -0.4 & -0.129 \\ \text { \% of initial } & +0.2 & +8.8 & +7.8 & +7.3 & -3.6 & +28.6 & -0.9 & -0.8 & -19.2 \\ \text { g per year } & +0.14 & +0.38 & +0.99 & +0.03 & -0.012 & +0.39 & -0.13 & -0.03 & -0.011\end{array}$

Slope of the drumlin

$\begin{array}{llllllllll}\text { A 0-10 } & -2.9 & -0.6 & -0.6 & \mathrm{x} & +0.008 & -0.2 & -0.5 & -0.3 & +0.005 \\ \text { A/Baf 10-20 } & -0.9 & -0.6 & -0.2 & \mathrm{x} & +0.002 & -0.3 & -0.6 & -0.2 & -0.002 \\ \text { Baf 20-35 } & -2.1 & -0.9 & -0.4 & \mathrm{x} & +0.002 & -0.5 & -0.9 & -0.4 & -0.005 \\ \text { Baf 35-50 } & -6.2 & -1.0 & -0.3 & \mathrm{x} & +0.001 & -0.6 & -0.9 & -0.6 & -0.006 \\ \text { ELg 50-70 } & -7.0 & -1.7 & -1.0 & \mathrm{x} & -0.022 & -0.8 & -1.2 & -0.8 & -0.009 \\ \text { Bt 70-100 } & -0.2 & -0.1 & +1.6 & \mathrm{x} & -0.015 & -0.8 & -1.3 & +0.2 & +0.022 \\ \text { Bt 100-120 } & +2.3 & +0.8 & +2.4 & \mathrm{x} & +0.004 & -0.5 & -0.7 & +0.4 & +0.028 \\ \text { Total } & -17.0 & -4.1 & +1.5 & \mathrm{x} & -0.020 & -3.7 & -6.1 & -1.7 & +0.033 \\ \text { \% of initial } & -2.5 & -13.0 & +1.8 & \mathrm{x} & -2.0 & -25.5 & -43.9 & -3.9 & +4.7 \\ \text { g per year } & -1.42 & -0.34 & +0.13 & \mathrm{x} & -0.002 & -0.31 & -0.51 & -0.14 & +0.003\end{array}$

* See smoothed thickness and weight of prisms in Tables 1 and 2, respectively. $\mathrm{x}$, undetermined.

Increase in amounts $4.4 \%$ on the summit, decrease in amounts $3.6 \%$ on the slope. 
became ever more significant. The $3.6 \%$ decrease in chemical sources in soil on the slope, compared to the initial values in till, is quite uniform by horizons through the entire Luvisol section, only aluminium being accumulative within the Bt-horizon. This situation corresponds to granulometric status (Table 2). Against the background of denudation processes that developed on the slope during the Holocene, lessivage and argilluviation are evident. These phenomena have been found to be favoured on northern and/or northeastern slopes (Hunckler \& Schaetzl, 1997). Burnett \& Franzmeier (1997) suggested that carbonate minerals and/or silica, or both, could be responsible for weak cementation, while aluminium and iron enhanced its effect on the genesis of Oxyaquic Hapludalf on calcareous till. Pedogenetic breakdown of carbonates over time led to the progressive development of the cambi-argillic horizon in depth; due to its enrichment with aluminium and iron, an increase in the amounts of chemical constituents can also be suggested.

\section{Changes in soil composition and properties during the last 2.5 decades}

As a result of clear-cutting on the slope and selection felling on the summit of the drumlin the uneven thin layer of the Mull-type ground litter has almost disappeared during a short time. Owing to the activity of soil mesofauna, considerable mixing of aboveground litter residues with the epipedon stratum has continued. An increase in the depth of epipedon at the expense of the underlying Baf-horizon has taken place on the slope where humus status has only slightly changed (Table 4). The increase in the $\mathrm{C}: \mathrm{N}$ ratio and the decrease in the amount of humic acids give evidence of the decline in the intensity of humification there. The dynamics of free fulvic acids and fulvic complexes bound in the crystal lattice of clay minerals (hydrolysate of $0.5 \mathrm{M} \mathrm{H}_{2} \mathrm{SO}_{4}$ ) as well as total solubility of humus points to weakened humification in the process of the transformation of the Baf- (amorphous-Fe-accumulative) horizon into the epipedon. It is possible that this transformation can take place in the further progress of humusaccumulative phenomena in depth, as has been suggested on the basis of initial pedogenesis (Graham et al., 1995; Reintam, 1995) and the effects of forest management (Knoepp \& Swank, 1997).

A significant decrease in the percentage of organic carbon and humic acids (degree of humification) and an increase in total solubility and fulvicity of humus were characteristic of the Luvisol section on the drumlin summit. At the same time, changes in carbon and nitrogen supplies, induced by an increase in soil compaction and in the value of bulk density, were expressed to a lesser extent (Table 4). Against the background of the decrease in carbon percentage, even an increase in its supply in the thin compacted top of the epipedon was observed. These phenomena can be caused by the dynamics of the plant community as a result of the impact of forest cutting/felling on the moisture and bicoenotic 
Table 4. Changes in the composition of humus during the last $22-25$ years ( $\pm \%$ of organic carbon)

\begin{tabular}{c|c|c|c|c|c|c|c}
\hline \multirow{3}{*}{ Characteristics } & \multicolumn{3}{|c|}{ Summit of the drumlin } & \multicolumn{4}{c}{ Slope of the drumlin } \\
\cline { 2 - 8 } & $\mathrm{A}^{\prime}$ & $\mathrm{A}^{\prime \prime}$ & $\mathrm{Baf}$ & $\mathrm{A}^{\prime}$ & $\mathrm{A}^{\prime \prime} / \mathrm{Baf}$ & $\mathrm{Baf}^{\prime}$ & $\mathrm{Baf}^{\prime \prime}$ \\
& $0-6(10)$ & $6-20$ & $20-30$ & $0-10$ & $10-20$ & $20-35$ & $35-50$ \\
\hline
\end{tabular}

$\%$ of soil

$\begin{array}{clllllrr}\text { organic C } & -1.56 & -1.39 & -0.18 & -0.20 & +0.26 & -0.06 & +0.07 \\ \mathrm{~N} & -0.16 & -0.06 & 0.00 & -0.08 & +0.04 & 0.00 & 0.00 \\ \mathrm{C}: \mathrm{N} & +4.6 & -6.1 & -4.5 & +6.4 & -2.8 & -1.1 & +2.3\end{array}$

$\mathrm{kg} \mathrm{m}^{-2}$

$\begin{array}{rccccccc}\text { organic C } & +0.77 & -0.60 & -0.31 & -0.36 & +0.36 & -0.21 & +0.02 \\ \mathrm{~N} & -0.01 & 0.0 & -0.03 & -0.09 & +0.03 & -0.01 & -0.01\end{array}$

Humic acids

$\begin{array}{lrrrrrrr}\text { fr. } 1 & -2.8 & -3.5 & -9.7 & -3.2 & -0.4 & -0.7 & +0.1 \\ 2 & 0.0 & -2.8 & -3.3 & -1.0 & +1.9 & +1.6 & -1.7 \\ 3 & -0.6 & +0.9 & -0.6 & +0.8 & +0.9 & -1.9 & -1.3 \\ \Sigma & -3.4 & -5.4 & -13.6 & -3.4 & +2.4 & -1.0 & -2.9\end{array}$

Fulvic acids

$\begin{array}{lcrrrrrr}\text { fr. 1a } & +1.1 & +2.8 & +0.2 & +0.8 & +3.3 & -4.7 & -6.2 \\ 1 & +3.5 & +20.7 & +5.0 & -4.5 & -0.3 & +5.3 & +6.1 \\ 2 & -8.6 & +9.7 & +15.5 & -2.1 & -2.9 & +3.5 & -5.0 \\ 3 & +3.5 & +6.5 & +2.8 & +2.7 & +1.0 & +9.3 & +3.8 \\ \Sigma & -0.5 & +39.7 & +23.5 & -3.1 & +1.1 & +13.4 & -1.3 \\ & & & & & & & \\ \text { 0.5 } \mathrm{M} \mathrm{H}_{2} \mathrm{SO}_{4} \text { hydrolysate } & +3.1 & +3.5 & +6.3 & +1.1 & +6.1 & +1.4 & +3.4 \\ & & & & & & & \\ \text { Total soluble } & -0.8 & +37.8 & +16.3 & -5.4 & +9.6 & +13.8 & -0.8 \\ \text { Insoluble (humins etc.) } & +0.8 & -37.8 & -16.3 & +5.4 & -9.6 & -13.8 & +0.8 \\ & & & & & & & \\ \text { Humic acid: fulvic acid } & -0.10 & -0.58 & -0.38 & -0.05 & +0.04 & -0.07 & -0.04 \\ \text { 1st fraction:2nd fraction } & +2.8 & +0.4 & -1.0 & -0.5 & +0.1 & -0.1 & +0.8 \\ & & & & & & & \\ \text { In decalcinate (\% of soil) } & & & & & & & \\ \mathrm{Fe}+\mathrm{Al} & +0.02 & -0.20 & -0.10 & -0.32 & -0.06 & -0.02 & +0.15 \\ \mathrm{Fe} & +0.13 & -0.05 & 0.00 & -0.01 & +0.01 & 0.00 & 0.00 \\ \mathrm{Al} & -0.11 & -0.15 & -0.10 & -0.31 & -0.07 & -0.02 & +0.15 \\ \mathrm{Ca} & +0.14 & +0.07 & +0.08 & +0.14 & +0.13 & +0.08 & +0.07 \\ \mathrm{Mg} & +0.04 & +0.03 & +0.01 & +0.07 & +0.06 & +0.05 & +0.07\end{array}$

relationships (Zobel, 1993), as well as by natural cyclicity in the rate of humification and mineralization of root residues in changed site conditions. A significant increase in the quota of Ca-humic-fulvic complexes in humus, and alkaline earths contained in decalcinate seems to indicate intensified mineralization of both falling and ground litter there. The expanded $\mathrm{C}: \mathrm{N}$ ratio serves as a clear evidence of the weakening of nitrogen bridges in the structure of humus acids (Flaig, 1971), which can advance substitution and fixation of fulvic acids in the structure of clay minerals. 
Changes in physicochemical properties (Table 5) have been induced by changes in humus status. Considerable acidification has taken place in the entire solum, while the extrinsic nature of the process, actuated by fulvic acids (Pedro et al., 1974), is particularly well expressed by appreciable changes in aqueous pH. Crystallochemical processes (intrinsic acidification after Pedro et al., 1974) have also been of importance, as a result of which the content of exchangeable aluminium increased and $\mathrm{pH}-\mathrm{level}$ in salt suspension decreased mainly in the uppermost solum on the drumlin summit. Below the stagnation of seasonal perched water and deeper, changes in exchangeable acidity and mobile aluminium were insignificant or entirely absent. A tendency for the quota of aluminium to decrease and a simultaneous increase in the share of alkaline earths and iron in complexiation of humus acids (Table 4) can also be interpreted as intensified mobilization of aluminium in two upper horizons. Seasonal changes can be excluded because there were no seasonal differences in either sampling.

Table 5. Changes in physicochemical properties and content of nonsiliceous oxides during the last 22-25 years ( \pm units)

\begin{tabular}{|c|c|c|c|c|c|c|c|c|c|c|}
\hline \multirow{2}{*}{$\begin{array}{l}\text { Horizon and } \\
\text { depth, } \mathrm{cm}\end{array}$} & \multicolumn{2}{|c|}{$\mathrm{pH}$} & \multirow{2}{*}{$\begin{array}{l}\text { BEC, } \\
\frac{\mathrm{cmol}}{\mathrm{kg}}\end{array}$} & \multirow{2}{*}{$\begin{array}{c}\text { BS, } \\
\%\end{array}$} & \multirow{2}{*}{$\begin{array}{c}\mathrm{Al}^{3+}, \\
\mathrm{mg} / \mathrm{kg}\end{array}$} & \multirow{2}{*}{$\begin{array}{c}\text { Free } \\
\mathrm{Fe}_{2} \mathrm{O}_{3}, \\
\%\end{array}$} & \multicolumn{3}{|c|}{ Amorphous, $\%$} & \multirow{2}{*}{$\begin{array}{l}\mathrm{Fe}- \\
\text { activi- } \\
\text { ty, \% }\end{array}$} \\
\hline & $\mathrm{H}_{2} \mathrm{O}$ & $\begin{array}{c}1 \mathrm{M} \\
\mathrm{KCl}\end{array}$ & & & & & $\mathrm{Fe}_{2} \mathrm{O}_{3}$ & $\mathrm{Al}_{2} \mathrm{O}_{4}$ & $\mathrm{SiO}_{2}$ & \\
\hline
\end{tabular}

Summit of the drumlin

$\begin{array}{lrrrrrrrrrr}\text { A }^{\prime} \text { 0-6 (10) } & -0.7 & -0.4 & -4.4 & +2 & +6 & -0.3 & 0.0 & 0.0 & +0.1 & +47 \\ \text { A }^{\prime \prime} \text { 6(10)-15(20) } & -1.2 & -0.1 & -6.4 & -10 & +2 & -0.1 & +0.1 & +0.1 & 0.0 & +28 \\ \text { Baf 20-30 } & -0.8 & -0.7 & -0.5 & -4 & +9 & -0.2 & 0.0 & -0.2 & +0.1 & +7 \\ \text { Baf/ELg 35-50 } & -0.5 & -0.5 & +2.0 & +12 & +8 & -0.1 & 0.0 & -0.2 & +0.1 & +35 \\ \text { ELg 50-70 } & -0.5 & -0.4 & +2.4 & +5 & +1 & 0.0 & +0.1 & 0.0 & +0.1 & +16 \\ \text { Bt 45-55 } & -1.0 & -0.3 & +3.2 & +5 & +1 & -0.1 & 0.0 & +0.1 & +0.1 & +7 \\ \text { Bt 70-80 } & -1.0 & -0.3 & +13.1 & +13 & 0 & +0.1 & +0.1 & 0.0 & -0.1 & +2 \\ \text { Bt 100-110 } & -1.1 & -0.5 & -1.9 & -3 & 0 & -0.4 & +0.1 & +0.2 & 0.0 & +24 \\ \text { Bt 130-150 } & -0.9 & -0.4 & -1.8 & +1 & 0 & -0.1 & 0.0 & 0.0 & +0.1 & +5 \\ \text { C 170-200 } & 0.0 & 0.0 & 0.0 & -2 & 0 & -0.2 & 0.0 & 0.0 & +0.1 & +16\end{array}$

Slope of the drumlin

$\begin{array}{lrrrrrrrrrr}\text { A 0-10 } & -0.5 & +0.2 & -3.5 & +9 & -4 & -0.2 & +0.1 & 0.0 & +0.1 & +37 \\ \text { A/Baf 10-20 } & -0.7 & -0.2 & +0.5 & -14 & +2 & -0.2 & +0.1 & -0.1 & 0.0 & +40 \\ \text { Baf 20-35 } & -0.8 & -0.4 & -0.9 & -19 & 0 & -0.3 & 0.0 & 0.0 & 0.0 & +19 \\ \text { Baf 35-50 } & -0.8 & -0.2 & -2.4 & -5 & -1 & -0.3 & +0.1 & 0.0 & +0.1 & +26 \\ \text { ELg 50-80 } & -1.0 & -0.3 & +0.7 & -2 & 0 & +0.3 & +0.2 & 0.0 & 0.0 & -2 \\ \text { Bt 70-110 } & -1.0 & +0.7 & -0.5 & +4 & 0 & +0.3 & +0.2 & +0.2 & +0.1 & -1 \\ \text { Bt 110-140 } & -0.3 & +0.4 & -0.4 & +3 & 0 & +0.1 & +0.1 & +0.1 & +0.1 & +8 \\ \text { C 140-160 } & 0.0 & 0.0 & +3.5 & +1 & 0 & 0.0 & 0.0 & +0.1 & 0.0 & +11\end{array}$

$\mathrm{BEC}$, base exchange capacity; BS, base saturation. 
The impact of acid deposition on topsoil acidification was probable (Frey \& Palo, 1991). Since changes in light conditions and in the composition of the herb layer, induced by clear-cutting and selection felling, have resulted in the destruction of the moss layer, intensified breakdown of moss residues and mobilization of their mineral constituents cannot be neglected. Mosses of nemoral forests are rich in sesquioxides, among them aluminium (Kõlli, 1971) which can be partly transferred into exchangeable aluminium in the process of the decomposition of both the perished moss layer and forest litter.

The decrease in base exchange capacity (BEC, $\mathrm{cmol} \mathrm{kg}^{-1}$ ) in upper horizons and the increase and/or relative stability in deeper horizons (Table 5) are obviously due to changes in the amount and quality of humus (Table 4) and the content of clay and silt (Table 6). At that, the extremely high increase in clay and silt can represent the territorial (horizontal) heterogeneity of the till stratum. Although an increase in hydrolytical acidity still occurred in the ELg-horizon, the content of exchangeable bases was almost stable, or had only slightly decreased in the solum above seasonal perched water and increased below it. This was quite clearly evidenced by changes in BEC and base saturation. The latter has increased in the upper part of the epipedon on account of alkaline earths released as a result of mineralization of ground and falling litter, but decreased both in the lower part of the epipedon and in the upper part of the Baf-horizon (subsection of the greatest changes in the entire soil profile) due to the substitution of exchangeable aluminium in the colloidal complex. Alkaline earths, exchanged for aluminium and released thereupon, have been partially subjected to migration in the form of fulvates, but partially fixed in situ in the composition of saturated $\mathrm{R}_{2} \mathrm{O}_{3}$-fulvic complexes (Table 4). The stability and/or growth of base saturation in the middle and lower parts of the Luvisol section, characterized by seasonal perched water, argilluviation, and argillization, seem to indicate rather a transformative than eluvial nature of the processes affecting exchangeable bases. The lack of carbonates on the drumlin summit could have been related to their intensified leaching during only some decades, but also to the depth variability of till calcareousness at a short distance.

The increase in iron activity seems to have arisen from the tendencies towards a decrease in total nonsiliceous iron and an increase in amorphous iron (Table 5). Participation of the biogenic forms of the latter must be essential too (Zonn, 1982). There is reason to suppose that changes in the perched regime that have appeared after forest cutting and timber removal procedures have played an important role in changes in iron relationships. A tendency for nonsiliceous iron to decrease seems to be accompanied with the formation of ferri- and/or ferriferrous silicates in the process of argillization and argilluviation (Tables 5-7). Against the background of the decrease in the content of nonsiliceous sesquioxides, total iron was accumulative everywhere. The decrease in aluminium can be accounted for by changes in the interlayeral structure of clay minerals after the substitution of alkaline earths there and formation of aluminium pseudosols 
(Brindley, 1965). On the other hand, differences at a depth of 100-200 $\mathrm{cm}$ can scarcely be fully induced by contemporary pedogenetic phenomena, and horizontal heterogeneity of reddish-brown till is noteworthy. Regarding aluminium and alkaline earths, their variation coefficient at the $95 \%$ level of significance reached, for example, $15 \%$ and $23 \%$, respectively, and was in some other cases even higher (Reintam et al., 1977).

Table 6. Changes in the weight of granulometric fractions of soil during the last 22 (slope) to 25 (summit) years compared with the smoothed thickness of soil horizons from 1969-72 $\left( \pm \mathrm{kg} \mathrm{m}^{-2}\right)$

\begin{tabular}{c|c|c|c|c|c|c|c|c|c|c}
\hline \multirow{2}{*}{$\begin{array}{c}\text { Horizon and } \\
\text { depth, cm }\end{array}$} & \multicolumn{2}{|c|}{$\begin{array}{c}\text { Weight of soil } \\
\text { prisms }\end{array}$} & \multicolumn{3}{|c|}{ Fractions, mm } & \multicolumn{2}{c|}{$\begin{array}{c}\text { Corrected data } \\
\text { for 1969-72 }\end{array}$} & \multicolumn{3}{|c}{$\begin{array}{c}\text { Smoothed fractions, } \\
\mathrm{mm}\end{array}$} \\
\cline { 2 - 9 } & $\begin{array}{c}1969 / \\
1972\end{array}$ & 1994 & $1-0.01$ & $<0.01$ & Total & $\begin{array}{c}\text { Depth, } \\
\text { cm }\end{array}$ & $\begin{array}{l}\text { Weight, } \\
\mathrm{kg} \mathrm{m}^{-2}\end{array}$ & $1-0.01$ & $<0.01$ & Total \\
\hline
\end{tabular}

Summit of the drumlin

$\begin{array}{lrrrrrrrrrr}\text { A 0-10 } & 99.0 & 133.0 & +24.2 & +9.8 & +34.0 & 13.1 & 129.7 & 0.0 & +3.3 & +3.3 \\ \text { A 10-20 } & 117.0 & 140.0 & +14.0 & +9.0 & +23.0 & 11.5 & 134.5 & +0.2 & +5.3 & +5.5 \\ \text { Baf 20-30 } & 137.0 & 155.0 & -5.3 & +23.3 & +18.0 & 10.5 & 143.8 & -10.9 & +22.1 & +11.2 \\ \text { Baf 30-40 } & 147.0 & 170.0 & -8.3 & +31.3 & +23.0 & 10.7 & 157.3 & -16.8 & +29.5 & +12.7 \\ \text { ELg 40-50 } & 157.0 & 170.0 & -22.8 & +35.8 & +13.0 & 10.2 & 160.1 & -25.5 & +35.4 & +9.9 \\ \text { ELg/Bt 50-70 } & 318.0 & 370.0 & -64.7 & +116.7 & +52.0 & 17.2 & 273.5 & -28.2 & +124.7 & +96.5 \\ \text { Bt 70-90 } & 328.0 & 350.0 & -42.3 & +64.3 & +22.0 & 20.0 & 328.0 & -42.3 & +64.3 & +22.0 \\ \text { Bt 90-120 } & 487.0 & 540.0 & +27.4 & +25.6 & +53.0 & 32.0 & 519.5 & +4.0 & +16.5 & +20.5 \\ \text { Bt 120-180 } & 998.0 & 1080.0 & +7.5 & +74.5 & +82.0 & 60.6 & 1008.0 & 0.0 & +72.0 & +72.0 \\ \text { Total } & 2788.0 & 3108.0 & -70.3 & +390.3 & +320.0 & 185.8 & 2854.4 & -119.5 & +373.1 & +253.6\end{array}$

Slope of the drumlin

$\begin{array}{lrrrrrrrrrr}\text { A 0-10 } & 105.8 & 100.0 & -3.8 & -2.0 & -5.8 & 9.6 & 101.6 & -0.3 & -1.3 & -1.6 \\ \text { A 10-20 } & 114.3 & 120.0 & +4.0 & +1.7 & +5.7 & 10.4 & 118.8 & +0.3 & +0.9 & +1.2 \\ \text { Baf 20-35 } & 192.5 & 188.0 & -1.6 & -2.9 & -4.5 & 14.9 & 191.2 & -0.6 & -2.6 & -3.2 \\ \text { Baf 35-50 } & 222.9 & 217.0 & -4.7 & -1.2 & -5.9 & 14.6 & 217.0 & +0.1 & -0.1 & 0.0 \\ \text { ELg 50-70 } & 301.1 & 330.0 & +17.3 & +11.6 & +28.9 & 21.4 & 322.2 & 0.0 & +7.8 & +7.8 \\ \text { Bt 70-100 } & 471.2 & 480.0 & +2.3 & +6.5 & +8.8 & 30.3 & 475.8 & -1.1 & +5.3 & +4.2 \\ \text { Bt 100-120 } & 317.3 & 330.0 & +12.2 & +0.5 & +12.7 & 21.1 & 334.8 & -0.6 & -4.2 & -4.8 \\ \text { Total } & 1725.1 & 1765.0 & +25.7 & +14.2 & +39.9 & 122.3 & 1761.4 & -2.2 & +5.8 & +3.6\end{array}$

Such heterogeneity in the composition of till could certainly have an impact on changes in the weight of granulometric fractions and chemical constituents of soil on the drumlin summit where repeated sampling from the former pit proved impossible (Tables 6 and 7). Nevertheless, as a result of forest cutting and management activity, pressure on the solum has led to considerable compaction and an increase in bulk density. The $20-30 \%$ increase in the bulk density in the upper $(\mathrm{A}+\mathrm{Baf})$ subsection and the $5-10 \%$ increase in the intermediate and deeper $(\mathrm{ELg}+\mathrm{Bt})$ subsection were characteristic of recent decades. In the middle of the profile, the locally increased content of silt and clay seems to be the main 
reason for the changes in textural and chemical relationships in soil on the drumlin summit. Compressed subsidence was also especially remarkable on the drumlin summit, making up about $4 \%$ of the initial status - the soil section was $5.8 \mathrm{~cm}$ deeper in 1969 than in 1994. At the same time, changes in the thickness of the mere $20 \mathrm{~cm}$ epipedon were up to $4.6 \mathrm{~cm}$ there. Against the background of intensive weathering of the sand fraction and simultaneous accumulation of silt and clay fractions, the total amount of fractions had increased $9 \%$ on the drumlin summit (Table 6). The average annual rate of physical clay increment was $54 \mathrm{~g} \mathrm{~m}^{-2} \mathrm{~cm}^{-1}$ there, being about two times as intensive under seasonal perched aquic conditions at a depth of 40-70 $\mathrm{cm}$. Considering all features, this subsection could be characterized by intensified ferrolysis (Brinkman, 1979) which was accompanied by argilluviation from the biologically activized uppermost

Table 7. Changes in the weight of chemical constituents of soil during the last 22 (slope) to 25 (summit) years compared with the smoothed thickness of horizons from 1969-72 $\left( \pm \mathrm{kg} \mathrm{m}^{-2}\right)^{*}$

\begin{tabular}{|c|c|c|c|c|c|c|c|c|}
\hline $\begin{array}{c}\text { Horizon and } \\
\text { depth, cm }\end{array}$ & $\mathrm{Si}$ & $\mathrm{Fe}$ & $\mathrm{Al}$ & $\mathrm{P}$ & $\mathrm{Ca}$ & $\mathrm{Mg}$ & K & $\mathrm{Mn}$ \\
\hline \multicolumn{9}{|c|}{ Summit of the drumlin } \\
\hline A $0-10$ & -0.3 & +0.3 & -1.0 & +0.20 & +0.2 & +0.6 & +0.6 & +0.094 \\
\hline A $10-20$ & +0.4 & +0.3 & -0.7 & +0.13 & 0.0 & +0.2 & +0.2 & +0.111 \\
\hline Baf $20-30$ & +3.9 & +0.9 & -0.6 & +0.01 & +0.1 & +0.3 & +1.4 & +0.077 \\
\hline Baf $30-40$ & +1.7 & +0.7 & +0.3 & +0.08 & 0.0 & +0.5 & +1.4 & +0.109 \\
\hline ELg 40-50 & -0.9 & +1.2 & +0.7 & -0.07 & +0.7 & +0.5 & -0.1 & +0.069 \\
\hline $\mathrm{ELg} / \mathrm{Bt} 50-70$ & +25.7 & +3.6 & +1.1 & +0.04 & +1.6 & +1.2 & +1.2 & +0.052 \\
\hline Bt $70-90$ & +1.4 & +1.1 & -1.4 & +0.01 & +0.8 & +0.5 & +2.0 & +0.120 \\
\hline Bt $90-120$ & +7.8 & -2.0 & -2.9 & +0.01 & 0.0 & +0.5 & +0.2 & +0.177 \\
\hline Bt $120-180$ & +20.1 & +0.4 & -0.2 & +0.24 & +1.3 & +0.9 & +1.3 & -0.044 \\
\hline Total & +59.8 & +6.5 & -4.7 & +0.65 & +4.7 & +5.2 & +8.2 & +0.765 \\
\hline$\%$ of initial & +5.7 & +11.1 & -2.8 & +16.0 & +20.2 & +33.8 & +17.1 & +55.3 \\
\hline g per year & +2392 & +260 & -188 & +26 & +188 & +208 & +328 & +31 \\
\hline
\end{tabular}

Slope of the drumlin

$\begin{array}{lclllllll}\text { A 0-10 } & -1.5 & -0.07 & -0.6 & +0.11 & 0.0 & +0.1 & -0.4 & +0.023 \\ \text { A 10-20 } & -3.1 & +0.14 & -0.6 & +0.16 & +0.3 & +0.2 & -0.7 & +0.015 \\ \text { Baf 20-35 } & -3.9 & +0.35 & -0.2 & +0.04 & +0.4 & +0.2 & -0.7 & +0.039 \\ \text { Baf 35-50 } & +1.9 & +0.14 & +0.8 & +0.19 & +0.5 & +0.2 & 0.0 & +0.031 \\ \text { ELg 50-70 } & -2.6 & +0.21 & +0.7 & +0.27 & +0.3 & 0.0 & -1.2 & +0.046 \\ \text { Bt 70-100 } & -2.5 & +0.70 & 0.0 & +0.38 & +0.5 & +0.5 & -2.6 & +0.132 \\ \text { Bt 100-120 } & -5.1 & -1.26 & -0.2 & +0.37 & +0.7 & 0.0 & -0.6 & +0.054 \\ \text { Total } & -16.8 & +0.21 & -0.1 & +1.52 & +2.7 & +1.2 & -6.2 & +0.340 \\ \text { \% of initial } & -2.5 & +0.7 & -0.1 & +152.0 & +25.2 & +15.0 & -14.7 & +48.6 \\ \text { g per year } & -764 & +9 & -5 & +69 & +123 & +57 & -282 & +15\end{array}$

* Smoothed thickness and weight of prisms see in Table 6.

Increase in initial sources $6.2 \%$ on the summit, decrease in initial sources $2.0 \%$ on the slope. 
subsection and argillization in situ on account of ferrosilicates and ferrous hydroxides. The increase in textural discontinuity due to the progress of argilluviation resulted in the development of the stagnic and surface gleyic pattern not only in root channels but also on the ped matrix of the Bt-horizon. According to Blume (1990), such attributes are stagnic in their nature but resemble reductomorphic formations against the background of the reddishbrown surface of tilly peds.

The chromic subsection, about $40-50 \mathrm{~cm}$ thick, is continuously accumulative with respect to fine particles and their constituents. An accumulation of biologically uptaken and absorbed chemicals has taken place namely here, while their release, mobilization, and recrystallization represent a special source of biogenic argillization. Partial redistribution of clay and fine silt neither did nor does eliminate the accumulative nature of the subsection. The reddish-brown subsection (Bt-horizon) below the perched zone was not only compacted due to argilluviation but also locally enriched with clay and silt as a result of more continuous argillization in situ. Naturally, the influence of spatial heterogeneity could have been more expressed here than elsewhere in other subsections. However, contemporary pedogenesis on the drumlin summit was intensive and accumulative despite an increase in agressive humus and acidity. On the drumlin slope, contemporary changes in texture (Table 6) resemble very much the changes characteristic of the entire Holocene (Table 2). Only some losses of fine earth that occurred during several millennia have been compensated for by a clear tendency towards accumulative phenomena that have developed against the background of the former lessivage.

The total weight of main chemical constituents had increased on the summit and decreased on the slope at a rate exceeding greatly the rate characterizing the entire Holocene (Tables 3 and 7). Except for aluminium, 35-65\% of accumulation has taken place within the upper half-metre as a result of intensive biological processes, including probable neosynthesis of secondary ferrisilicates with alkaline earths in their interlayeral structure and amorphous hydroxides fixing released phosphorus. Only less than $10 \%$ of accumulated silica had concentrated there. Although in different climatic conditions, a similar situation was determined by Graham et al. (1995) in the modern development of Typic Xerorthent on the weathering product of diorite. The greatest portion of total accumulation (Table 7) belonged to the transitional perched zone and to the upper part of argillic Bt. Except for phosphorus and manganese, 33\% (magnesium) to 55\% (iron) of accumulation had taken place namely in this subsection, while aluminium, too, was accumulative here. Such a profile distribution of chemical sources was in quite good correlation with changes in texture (Table 6) and seems to have arisen as a result of intensification of ferrolysis, lessivage (pseudopodzolization), argillization in situ, and argilluviation against the background of obvious horizontal heterogeneity of till as interpreted above. Owing to this complex of processes, cementation and compaction of the subsection had probably progressed. According to Wilson et al. (1996), wetting-drying cycles are important factors, 
besides allophane, iron oxide, etc., influencing the process of cementation in the seasonally perched zone. Clear-cutting and selection felling usually favour alternation of seasonal overmoistening and drying up of the solum at the juncture of pedogenetic discontinuity (horizons of different texture), because the lower is the stocking density of the stand the greater are changes in moisture relationships (Pork et al., 1977) and in subsequent changes in the intensity of soil processes.

The remaining portion of total accumulation (17-27\%) was established in the deep (depth $90 \mathrm{~cm}$ ) argillic horizon. Only concerning silica and calcium, it was much greater and concerning aluminium, again negative. Loss of iron has occurred in the middle of the Bt-horizon, which could be due to the heterogeneity of till. However, the upward removal of ferrous compounds, formed as a result of seasonal reduction in the deeper part of the perched zone and subsequent reoxidation higher up, could be plausible.

Changes in chemical constituents on the drumlin slope were principally similar (Table 7) except that besides aluminium also silica and potassium have become lost, and changes in the thickness of the solum were insignificant there. Erosion could have taken place after clear-cutting although, morphologically, the surface was unchanged and the epipedon had even increased in depth.

\section{CONCLUSIONS}

Leaching of carbonates, weathering of sand particles, and accumulation of silt and clay have been and still are going on in soils on reddish-brown calcareous till both on the drumlin summit and slope. The mean rate of annual increment of organic carbon and nitrogen in the solum of $120-180 \mathrm{~cm}$ was $654-696 \mathrm{mg} \mathrm{m}^{-2}$ and 54-62 $\mathrm{mg} \mathrm{m}^{-2}$ during the Holocene, respectively. Organic agents, amounting to $540-570 \mathrm{mg} \mathrm{m}^{-2} \mathrm{yr}^{-1}$ of carbon and nitrogen in the upper half-metre, have ensured the progress of chromic properties beside the ochric and/or umbric epipedon there. The yellowish-brown Baf-horizon below the epipedon is characteristic of the Luvisol section above the whitish ELg-horizon lying within the belt of the seasonal perched regime. This sequum represents the fossil stagnigleyic formation of primary Gelic Gleysol that developed under the permafrost during the Baltic Ice Lake Stage about 12000-10 400 BP. Its automorphic transformation that has reached the present composition and morphology must have started in the Litorina Stage about 8000 BP. Continuous progress of stagnic, argillic, and argilluvic properties resulted in the contemporary sequence of horizons A-Baf-ELg-Bt(Bmt)-C in the studied Chromi-Stagnic Luvisol sections. The initial stratum of calcareous reddish-brown till was $13-18 \mathrm{~cm}$ thinner and $10-11 \%$ lighter than the modern solum, while the average annual upgrowth of $11-15 \mu \mathrm{m}$ was recorded as the total outcome of Holocene pedogenesis. A tendency towards an increase in the smoothed weight of textural and chemical constituents of soil on the drumlin summit gives evidence of the 
prevalence of spatial and temporal biopedogenetic accumulation there. Against the background of lessivage, argilluviation, and argillization in situ, denudation and decrease in the initial weight of till occurred on the northeastern drumlin slope.

As a result of changes in the stocking density of stands and in the forest management, ground litter has disappeared during a short time, and an increase in the depth of epipedon has been established. With a decrease in the percentage of organic carbon, its supply changed to a lesser extent (due to considerable compaction, up to $20-30 \%$ in the upper half-metre), and an increase in the solubility and fulvicity as well as a decrease in the degree of humification and perfection (according to the $\mathrm{C}: \mathrm{N}$ ratio) of humus has taken place. Changes in the composition of decalcinate demonstrate an increased role of $\mathrm{Fe}, \mathrm{Ca}$, and $\mathrm{Mg}$ and a decreased role of $\mathrm{Al}$ in complexiation of humus substances. Considerable extrinsic acidification, surpassing intrinsic acidification, has been characteristic of contemporary pedogenetic changes. Intensive mobilization of exchangeable $\mathrm{Al}^{3+}$ in the epipedon and in the uppermost part of the Baf-horizon has also taken place. This has resulted not only in an increase in actual acidity but, by layers, also in cation exchange capacity and base saturation. Against the background of the decrease in the content of nonsiliceous iron, the accumulation of amorphous iron, increase in iron activity as well as formation of secondary Fe-silicates were established.

Contemporary changes in textural and chemical constituents of soil are first of all caused by compaction of soil and an increase in bulk density as well as by rapid intensification of biogenic and/or hydrobiogenic accumulation. It was possible to distinguish three subsections of clay and chemical accumulation: the first subsection within the upper half-metre represents an outcome of intensified biogenic argillization caused by recrystallization and fixation of mobilized chemicals; the second subsection in the perched zone appears to be of illuvioaccumulative origin, which is the result of complicated association of ferrolysis, argillization and argilluviation against the background of horizontal till heterogeneity; the third subsection within the deep argillic horizon is of till origin. Depending on concrete chemical constituents, the rates of main accumulation in these subsections are $35-65,33-55$, and $17-27 \%$, respectively. Aluminium was accumulative only within the perched zone. Trends and rates of changes in the textural and chemical composition do not exclude heterogeneity of the studied and compared sections.

\section{ACKNOWLEDGEMENTS}

This study was supported by the Estonian Science Foundation (grant No. 2669).

I would like to thank the whole team of laboratory assistants for collaboration in 1969-72, especially the research assistant Raja Kährik, who has contributed to 
our research up to the present and has carried out all laboratory analyses of recurrent studies. Special thanks are due to Toomas Frey, the executive head of Estonian IBP investigations and founder of the Vooremaa Forest Ecology Station, for his kind help, valuable suggestions, and fruitful cooperation in the present study as well as other research. I am grateful to Ester Jaigma for the revision of the English manuscript. I would also like to thank Chang Wang, Kristian Dalsgaard, and Anto Raukas for their valuable and constructive comments on the manuscript.

\section{REFERENCES}

Arinushkina, E. V. 1970. Rukovodstvo dlya khimicheskogo analiza pochv. University Press, Moscow (in Russian).

Blume, H.-P. 1990. Soils with gleyic and with stagnic attributes. In Transactions of $14^{\text {th }}$ International Congress of Soil Science, V. Commission V, pp. 49-54. Kyoto, Japan.

Brindley, C. W. 1965. Chlorite Minerals. The X-Ray Identification and Crystal Structures of Clay Minerals. Moscow (Russian translation).

Brinkman, R. 1979. Ferrolysis, a Soil-Forming Process in Hydromorphic Conditions. Pudos, Wageningen.

Bryant, R. B. \& Arnold, R. W. 1994. Quantitative modeling of soil forming processes. Soil Sci. Soc. Am. Spec. Publ., 39. ASA, CSSA, SSSA. Madison, WI.

Buol, S. W., Hole, F. D. \& McCracken, R. J. 1989. Soil Genesis and Classification. Third Edition. The Iowa State University Press, Ames.

Burnett, S. L. \& Franzmeier, D. P. 1997. Pedogenesis and cementation in calcareous till in Indiana. Soil Sci. Soc. Am. J., 61, 4, 1098-1104.

Creemens, D. L. 1995. Pedogenesis of Cotiga Mound, a 2100-year-old woodland mound in Southwest West Virginia. Soil Sci. Soc. Am. J., 59, 5, 1377-1388.

Flaig, W. 1971. Organic compounds in soil. Soil Sci., 111, 1, 19-33.

Frey, T. 1977. IBP research at the Vooremaa Forest Ecology Station. In Spruce Forest Ecosystem Structure and Ecology, 1 (Frey, T., ed.). Estonian Contributions to the IBP, 11, 21-36.

Frey, J. \& Palo, A. 1991. Deposition loads in Voore spruce forest and state of deterioration of trees. In Problems of Contemporary Ecology. Ecology and Energetics (Frey, T., ed.), pp. 29-32. Tartu.

Graham, R. C., Ervin, J. O. \& Wood, H. B. 1995. Aggregate stability under oak and pine after four decades of soil development. Soil Sci. Soc. Am. J., 59, 6, 1740-1744.

Huckriede, H., Clasen, S. \& Meischner, D. 1996. Hydrographic and climatic changes recorded in Holocene sediments of the Central Baltic Sea. Baltica, 9, 76-91.

Hunckler, R. V. \& Schaetzl, R. J. 1997. Spodosol development as affected by geomorphic aspect, Baraga County, Michigan. Soil Sci. Soc. Am. J., 61, 4, 1105-1115.

Kern, J. S. 1994. Spatial patterns of soil organic carbon in the Contiguous United States. Soil Sci. Soc. Am. J., 58, 2, 439-455.

Knoepp, J. D. \& Swank, W. T. 1997. Forest management effects on surface soil carbon and nitrogen. Soil Sci. Soc. Am. J., 61, 3, 928-935.

Kõlli, R. 1971. On the relations between vegetation and soils in ecosystems on brown forest and brown pseudopodzolic soils. In Biological Productivity and Regimes of Soils. Trans. Estonian Agricultural Academy, 75, 165-202.

Langley-Turnbaugh, S. J. \& Bockheim, J. G. 1997. Time-dependent changes in pedogenetic processes on marine terraces in Coastal Oregon. Soil Sci. Soc. Am. J., 61, 5, 1428-1440. 
Mermut, A. R. \& St. Arnaud, R. J. 1981. Microband fabric in seasonally frozen soils. Soil Sci. Soc. Am. J., 45, 3, 578-586.

Pedro, G., Jamagne, M. \& Begon, J. C. 1974. Two main trends of acid soil formation in temperatecold and humid zone. Pochvovedenie (Soviet Soil Science), 9, 3-13.

Ponomareva, V. V. 1957. To the method for the study of soil humus after I. V. Tyurin's scheme. Pochvovedenie (Soviet Soil Science), 8, 66-71.

Pork, K., Arold, U. \& Lutsar, V. 1977. Precipitation, evaporation, soil temperature and moisture in 1970 and 1971. In Spruce Forest Ecosystem Structure and Ecology, 1 (Frey, T., ed.). Estonian Contributions to the IBP, 11, 55-82.

Raukas, A., Saarse, L. \& Veski, S. 1995. A new version of the Holocene stratigraphy in Estonia. Proc. Estonian Acad. Sci. Geol., 44, 4, 201-210.

Reintam, L. 1985. Genetic characteristics of soils on red-brown moraine compared by the substance balance method. Soviet Soil Science, 17, 5, 13-22.

Reintam, L. 1990. Material-regime differentiation of soil profile in diagnostics and classification. In Soil Classification (Rozanov, B. G., ed.), pp. 12-19. UNEP, ISSS, Moscow.

Reintam, L. 1995. Temporal and spatial changes in organic agents in the progress of primary pedogenesis during thirty years. Proc. Estonian Acad. Sci. Ecol., 5, 3/4, 61-76.

Reintam, L. 1997a. Changes in the composition and properties of forest Stagnic Luvisol. In Problems of Contemporary Ecology. Temporal Changes in Estonian Nature and Environment (Frey, T., ed.), pp. 197-203. Tartu.

Reintam, L. 1997b. Pedogenetic changes in the quantity and distribution of textural and chemical soil constituents during thirty years. Proc. Estonian Acad. Sci. Biol. Ecol., 46, 3, 174-190.

Reintam, L. 1997c. Soil formation. In Geology and Mineral Resources of Estonia (Raukas, A. \& Teedumäe, A., eds.), pp. 298-306. Estonian Academy Publishers, Tallinn.

Reintam, L., Oja, A. \& Leedu, E. 1977. Soil characteristics of the Kallivere drumlin. In Spruce Forest Ecosystem Structure and Ecology, 1 (Frey, T., ed.). Estonian Contributions to the IBP, 11, 83-114.

Reintam, L. \& Kaasik, E. 1977. A study of the soil solution by means of lysimetric vessels and chromatographic columns. In Spruce Forest Ecosystem Structure and Ecology, 1 (Frey, T., ed.). Estonian Contributions to the IBP, 11, 115-142.

Reintam, L. \& Oja, A. 1978. Brown pseudopodzolic soils on the Kallivere drumlin. In Some Problems of Vooremaa Spruce Stands' Ecology (Kalamees, K., ed.). Year-Book of the Estonian Naturalists' Society, 66, 29-58.

Rozanov, B. G. 1975. Genetic Morphology of Soils. University Press, Moscow (in Russian).

Sokolov, I. A. \& Targulian, V. O. 1976. Soil and environment interactions: soil-memory and soilmoment. In Investigation and Use of Natural Environment, pp. 150-164. Moscow (in Russian).

Targulian, V. O., Sokolova, T. A., Birina, A. G., Kulikov, A. V. \& Tselishcheva, L. K. 1974. Arrangement, Composition and Genesis of Sod-Pale-Podzolic Soil Derived from Mantle Loams. Analytical Investigation. X International Congress of Soil Science. Moscow.

Wang Chang \& Arnold, R. W. 1973. Quantifying pedogenesis for soils with discontinuities. Soil Sci. Soc. Am. Proc., 37, 1, 271-278.

Wilson, M. A., Burt, R., Sobecki, T. M., Engel, R. J. \& Hipple, K. 1996. Soil properties and genesis of pans in till-derived Andisols, Olympic Peninsula, Washington. Soil Sci. Soc. Am. J., 60, 1, 206-218.

Zobel, M. 1993. Changes in pine forest communities after clear-cutting: a comparison of two edaphic gradients. Ann. Bot. Fennici, 30, 131-137.

Zonn, S. V. 1982. Iron in Soils. Nauka, Moscow (in Russian).

Zonn, S. V. 1986. Tropical and Subtropical Soil Science. Mir, Moscow.

Zonn, S. V. 1994. Development of genetic diagnostics of soils on the basis of elementary soil processes. Pochvovedenie (Eurasian Soil Science), 4, 12-20. 


\title{
HOLOTSEENI JA NÜÜDISAJA MUUTUSED NÄIVLEETUNUD METSAMULLAS
}

\section{Loit REINTAM}

Vooremaa Metsaökoloogia Katsejaama kahel proovialal - Kallivere voore lael ja kirdenõlval - uuriti aastail 1969-1972 ning 1994 muutusi pruunides näivleetunud muldades kogu holotseeni ning paari viimase aastakümne jooksul. Kordusuuringuteks kasutati esialgsetega samu kaeveid voore nõlval või voore lael asunud kaevest mõne meetri kaugusele rajatud uut kaevet, sest esialgne kaeve oli lüsimeetrite paigaldamise ja eemaldamisega rikutud. Mõlemal korral kasutati keemilisel analüüsil ja arvutustel samu meetodeid.

Pruuni näivleetunud mulla kolmeti-kihiselt diferentseerunud $A-B a f-E L g-B t-C$ profiil oli punakaspruunil karbonaatsel moreenil kujunenud liivaosakeste murenemise ning tolmu, savi ja enamiku keemiliste koostekomponentide akumulatsiooni tulemusel holotseenis toimunud osalise dekolmatatsiooni kui geoloogilis-pedogeneetilise protsessi ja sesoonse ülavee taustal. Praegusaegsed muutused on peamiselt seotud lage- ja harvendusraie mõjuga orgaanilise aine voole ning ülavee režiimile. Lisaks varisele allus ka osa huumusest mineralisatsioonile, kusjuures sellest johtuvad kaod olid märgatavad voore lael. Mulla tiheduse suurenemisest tingituna osutus orgaanilise aine varude kadu protsentuaalsest väiksemaks. Huumusainete lahustuvuse ja fulvaatsuse kasvu taustal vähenes humifikatsiooniaste ning $C: N$ suhte kaudu väljenduv huumuse täiuslikkus. Huumusainete kinnistumisel kasvas $\mathrm{Fe}, \mathrm{Ca}$ ja $\mathrm{Mg}$ ning kahanes $\mathrm{Al}$ osatähtsus. Samas suurenesid neeldunud $\mathrm{Al}^{3+}$ sisaldus ning mulla aktiivne happesus. Mittesilikaatse raudoksiidi vähenemisel suurenes selle amorfsete vormide osakaal, kasvas raua aktiivsus ning sekundaarsete Fe-silikaatide süntees. Pöördvõrdelised seosed alumiiniumi ja leelismuldmetallide vahel näitavad muutusi savimineraalide koostises. Märkimisväärne on ka nüüdisajal liivafraktsiooni murenemine ning peene komponendi (tolm ja eriti ibe) ja sellega seotud keemiliste koostekomponentide kogunemine nii kohapeal kui ka profiilisisese ümberpaigutamise teel. Voore lael võib see olla seotud ka moreeni horisontaalse, kuid mitte vertikaalse heterogeensusega.

\section{ГОЛОЦЕНОВЫЕ И СОВРЕМЕННЫЕ ИЗМЕНЕНИЯ В БУРО-ПСЕВДООПОДЗОЛЕННЫХ ЛЕСНЫХ ПОЧВАХ}

\author{
Лойт РЕЙНТАМ
}

На двух экспериментальных участках Лесоэкологической станции Вооремаа, расположенных на вершине и северо-восточном склоне Калливереского друмлина, в 1969-1972 и 1994 годах изучали изменения в буро- 
псевдооподзоленных почвах, произошедшие в течение всего голоцена и последних двух с половиной десятилетий. Для повторных исследований использовали либо те же самые разрезы (склон друмлина), либо разрез, заложенный на расстоянии нескольких метров от первичного, поскольку последний был поврежден в процессе заложения и удаления лизиметрических установок. В обоих циклах исследований пользовались одинаковыми методами анализа и расчетов.

Трехслойно дифференцированный буро-псевдооподзоленный профиль $A-B a f-E L g-B t-C$ образовался на красно-бурой карбонатной морене в результате выветривания песчаных и накопления пылеватых и илистых фракций и большинства химических составных. Эти процессы развивались на фоне декольматации почвенно-геологической природы и сезонного застоя верховодки. Современные превращения, главным образом, связаны с изменениями в потоках органического вещества и в застойном режиме влажности, вызванными сплошной и выборочной рубками леса. Помимо лесного опада, даже часть гумуса подверглась минерализации, причем последующие потери оказались большими на вершине друмлина. В то же время, в результате антропогенного уплотнения верхних горизонтов, плотность почвы увеличилась и потери в запасах гумуса оказались меньшими процентуальных потерь. На фоне увеличения растворимости и фульватности гумуса уменьшились степень гумификации и выражаемая отношением углерода к азоту зрелость гумусовых веществ. В закреплении гумусовых комплексов возросла роль железа и щелочных земель, а значение алюминия уменьшилось. При этом имели место увеличение содержания поглощенного алюминия и повышение активной кислотности. На фоне сокращения доли несиликатного оксида железа возросли значение его аморфных форм, активность железа и образование вторичных ферроферри-силикатов. Противопропорциональные изменения содержания алюминия и щелочных земель указывают на возможные изменения в составе вторичных минералов. Значительное выветривание песчаных фракций и накопление пылевато-илистых частиц и химических составных на месте образования и/или в результате лессивирования свойственны также современному почвообразованию. На вершине друмлина это может быть отчасти связано с горизонтальной (не вертикальной) гетерогенностью морены. 